\title{
Multiple Mini-Interview in Selecting Medical Students
}

HyeRin Roh ${ }^{1,7}$, Hee Jae Lee ${ }^{2}$, Sung Bae Park ${ }^{1}$, Jeong Hee Yang ${ }^{3,7}$, Dae-Joong Kim ${ }^{4}$, Sang Hyun Kim ${ }^{5}$, Seung-Joon Lee ${ }^{6}$ and Gibong Chae ${ }^{1}$

Departments of ${ }^{1}$ Surgery, ${ }^{2}$ Pharmacology, ${ }^{3}$ Family Medicine, ${ }^{4}$ Anatomy, ${ }^{5}$ Microbiology, ${ }^{6}$ Internal Medicine, and

${ }^{7}$ Clinical Performance Center, School of Medicine, Kangwon National University, Chuncheon, Korea

\section{의학전문대학원 신입생 선발에서의 Multiple Mini-Interview}

강원대학교 의학전문대학원 ${ }^{1}$ 외과학교실, ${ }^{2}$ 약리학교실, ${ }^{3}$ 가정의학교실, ${ }^{4}$ 해부학교실,

${ }^{5}$ 미생물학교실, ${ }^{6}$ 내과학교실, ${ }^{7}$ 진료능력개발센터

노혜린 ${ }^{1,7}$, 이희제 ${ }^{2}$, 박승배 $^{1}$, 양정희 ${ }^{3,7}$, 김대중 ${ }^{4}$, 김상현 $^{5}$, 이승준 ${ }^{6}$, 채기봉 $^{1}$

Purpose: Selecting medical students through interviews seems difficult and the reliability of the results is one of the major concerns. The purpose of this study was to investigate the reliability and acceptability of the Multiple Mini-Interview (MMI) in selecting medical students of Kangwon National University.

Methods: Eighty-four applicants participated in the MMI which consists of 3 8-minute stations that have 9 checklist items and 3 global items. The 3 domains that we chose were motivation to become a doctor, communication and interpersonal skills, and ethical decision-making. We placed 2 interviewers in each room. The interviewers were chosen from our faculty. We analyzed the reliability of the MMI with urGENOVA for PC. We conducted a survey of these applicants and interviewers. Results: The reliability was 0.791 . Students answered that the interview was impressive and enjoyable. Students were also satisfied with the level and quality of the MMI cases. They described that they were evaluated objectively. Interviewers also responded positively. They stated that more stations and more efforts to develop the cases were needed to improve the reliability and validity.

Conclusion: The MMI was acceptable to our applicants and faculty. It is reliable for assessing medical school applicants in Korea. We should develop more stations and better cases to increase the reliability and validity of the MMI.

Key Words: Admission interview, Medical students selection, Generalizability, Multiple mini-interview

서론

좋은 학생을 선발하는 것이 좋은 의사를 선발하는 시
작이기에 의학전문대학원의 선발면접은 매우 중요하다 [1]. 의학과 학생 선발면접에서는 불명예스러운 전문인 이 될 가능성이 있는 사람을 걸러내는 작용도 크다[2]. 이를 통해 대학은 사회에 대한 공정성의 책임을 다하게
Received: March 4, 2009 - Accepted: April 24, 2009 Corresponding Author: HyeRin Roh, Gibong Chae

Department of Surgery, Kangwon National University Hospital

17-1 Hyoja-3-dong, Chuncheon 200-701, Korea

TEL) 033-258-2306 CELL) 011-372-3621 FAX) 033-258-2169 E-mail) hyerinr@kangwon.ac.kr
Korean J Med Educ 2009 Jun; 21(2): 103-115. doi: 10.3946/kjme.2009.21.2.103.

(C) The Korean Society of Medical Education. All rights reserved. 
된다[3]. 선발면접은 의사가 되기를 원하는 다양한 그룹 의 응시자에게도 모두 공정한 평가의 기회를 제공해야 한다[3].

우리나라에서 주로 사용하는 의학과 학생 선발면접 형태는 다수의 면접관이 한 명 또는 다수의 응시자를 10 분 내외의 짧은 시간 동안 구술 면접하는 방식이다. 면접관들은 대개 면접 당일 모여 면접 문항과 채점표에 대해 파악한다. 면접관은 자신이 임의로 추출한 $1 \sim 5$ 개 의 질문을 응시자에게 하며, 응시자의 답변을 듣고 5 개 내외의 항목에서 총괄평가를 한다. 응시자 수가 많은 경우 면접관은 조를 나누어 맡은 학생들을 각각 면접한 다. 면접은 대부분 하루에 끝난다.

이러한 면접 형태는 평가의 신뢰도를 확보하기 어렵 다는 것이 단점이다. 평가가 짧은 시간에 이루어지며 면접관이 사전에 충분히 면접 문항을 볼 시간이 부족하 기 때문이다. 면접관은 면접문항의 평가목적을 제대로 파악하지 못하고 면접을 시작할 수도 있다. 또한 명확 한 채점 기준이 없어 같은 응시자에 대한 점수가 면접 관마다 다를 수 있다. 면접관이 질문하는 형태에 따라 질문의 의미가 달라질 수도 있다. 응시자마다 면접관이 달라지거나 평가문항이 달라져 형평성이 문제될 수 있 다. 따라서 이러한 면접에서는 면접관 간의 점수 차이 를 줄이기 어렵고 평가의 신뢰도, 더 나아가 면접의 필 요성까지 의심받게 된다. 면접 평가의 주된 오차 요인 중 하나는 면접관에서 나온다. 특히 면접의 결과가 선 발, 배치의 기능 등 중요한 교육적 의사결정에 사용될 경우 평가자와 관련된 신뢰도는 반드시 고려해야 할 대 상이 된다[4].

최근 객관구조화진료시험과 비슷한 형태로 진행되는 면접시험인 Multiple Mini-Interview (MMI)가 개발 되었다[5]. 객관구조화진료시험에서 학생들은 주어진 시간 내에 여러 개의 시험방을 차례로 돌면서 부여된 진료 과제를 수행하게 된다[6]. MMI 역시 여러 개의 면 접방을 차례로 돌면서 면접관과 함께 부여된 과제에 대 해 면접하게 된다[7,8]. Eva et al.[5]은 MMI를 통해 0.65 의 신뢰도를 확보할 수 있었다고 보고하였다.

본교에서는 2008학년도 의학전문대학원 신입생을 선
발하는 면접방법으로 $\mathrm{MMI}$ 를 시행하였다. 이에 저자들 은 본교에서 시행된 $\mathrm{MMI}$ 의 결과와 그 준비과정을 분 석해보았다. 이를 통해 $\mathrm{MMI}$ 의 신뢰도가 어떠한지, 면 접시험이 필요하겠는지, MMI 면접 형태에 대한 학생들 과 면접관들의 시각은 어떠하였는지, $\mathrm{MMI}$ 의 준비과정 은 신뢰도, 타당도, 공정성 등을 높이기 위해 충분하고 적절하였는지 등을 파악해보고자 하였다. 또한 개선할 사항이 무엇인지 살펴, 바람직한 $\mathrm{MMI}$ 의 실천 방안을 제시해보고자 하였다.

\section{대상 및 방법}

\section{1. 대상}

2007년도에 의학전문대학원 입학생 선발 면접에 응 한, 일반전형 응시자 84명을 대상으로 하였다. 이 중 남 학생이 37명(44.0\%), 여학생이 47명(56.0\%)이었다. 평 균 연령은 25.7세(21 33세)였다. 군대를 이미 다녀온 남학생이 27명으로, 전체 남학생의 $73.0 \%$ 를 차지하였 다. 이공계대학 출신이 75 명(89.3\%)이었으며, 석사 이 상 출신이 3 명 $(3.6 \%)$ 이었다. 서울에 거주하는 학생이 43 명 $(51.2 \%)$ 이었다.

\section{2. 면접방과 면접관 배치}

본교 입학전형회의에서 정한 가장 중요한 원칙은 기 밀 유지였다. 이 원칙에 따라 모든 면접을 하루 내에 끝 낼 것, 사례개발교수와 면접문항개발위원이 중심이 되 어 기밀을 유지하며 사례를 개발할 것, 기밀 유지를 철 저히 하기 위해 사례의 영역 선정이나 보완 등을 위한 자문패널 동원은 피할 것, 면접교수와 면접사례는 면접 전날 결정할 것, 실험적 연구는 면접 전날 저녁에 시행 할 것, 모든 면접관은 교수로 할 것, 표준화환자는 활용 하지 말 것 등의 세부 원칙을 결정하였다. 하루에 동원 이 가능한 면접교수의 수는 18 명이었다. 입학전형회의 에서는 한 면접방에 2 명의 면접관이 함께 들어가도록 하였다. 면접장면은 연구목적으로도 녹화나 녹음을 하 
Fig. 1. Distribution of the Interviewers in Each Station

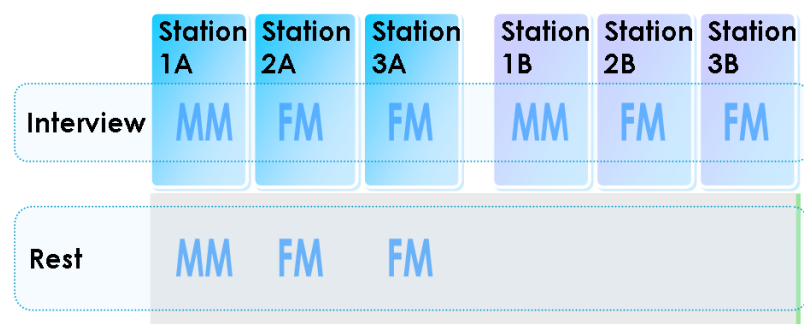

M: Male interviewer, F: Female interviewer.

지 않기로 하였다.

면접교수의 휴식시간 등을 고려하여 면접방은 총 3개 로 하기로 하였다. 3 개의 방을 2 방 복제하여, 동시에 6 개의 면접방이 운영되었다. 6 개의 면접방에는 각각 2 명 의 교수가 면접관으로 참여하였다. 남은 교수들은 휴식 하였다가 교대하여 면접관으로 참여하였다(Fig. 1).

면접교수는 되도록 객관구조화진료시험, 구술시험, 면접 등의 경험이 있는 교수 위주로 선발하였다. 면접 교수 중 남자는 12 명, 여자는 6 명이었다. 면접교수의 평 균 연령은 38.4세(32 52세)였다. 기초의학 전공 교수 5 명이 참여하였다. 임상의학 전공 교수는 총 13 명이 참 여하였다. 이들 중 5 명이 내과계열이었다. 외과 계열은 총 6 명이 참여하였다. 이외 진단검사의학 전공 1 명과 마취과 전공 1 명으로, 전공은 다양하였다. 정신과 전공 교수는 참여하지 않았다.

\section{3. 평가 영역과 주제 선정}

3 개의 면접방별로 각각 다른 영역을 평가하였다. 평 가 영역은 입학전형위원회에서 선정하였다. 평가 영역 으로는 대학졸업성적이나, 영어, 의학교육입문검사 등 에서 평가하기 어려운 분야, 의학전문대학원 교육으로 계발되거나 변화하기 어려운 분야, 본교의 교육목표 등 을 고려하여 결정하였다. 직업선택 동기, 의사소통과 대 인관계, 가치관과 태도 등이 평가 영역으로 최종 선정 되었다.

\section{4. 사례 및 채점표 개발}

사례 개발을 위해 별도의 면접문항개발소위원회를 입학전형위원회 산하에 구성하였다. 여기에는 교육평가 전문가 1 인과 함께 각 영역별 전문가 1 인, 입학전형위 원회 간사 1 인 등 총 5 명이 참가하였다.

각 영역별로 각각 3 개의 시험 사례를 개발하였다. 사 례는 면접문항개발 위원을 포함하여 총 9명의 교수에게 의뢰하여 개발하였다. 사례는 추상적인 이론을 묻기보 다 구체적인 상황을 주고 여기에서의 행동방침이나 과 거의 행동을 묻는 것으로 하였다. 의학적 상황에 익숙 하지 않은 학생들을 고려하여, 쉬운 의학적 상황이나 비의학적 상황으로 제시하였다. 미리 준비된 답변보다 는 본인이 가지고 있는 본연의 생각과 모습이 드러날 수 있도록 사례와 질문을 구성하였다. 암기된 전문지식 을 회상하여 답하기 보다는 활성 지식을 논리적 사고를 바탕으로 이끌어내는 데 주력하였다. 남녀의 차이, 나 이, 전공에 따라 더 유리하거나 불리하지 않도록 상황 을 만들었다.

사례는 학생들이 면접 전에 내용을 파악하기 쉽도록 2개의 문단으로 짧게 구성하였다. 그 밑에는 면접방에 들어가서 우선 답할 핵심 질문 3가지를 제시하였다. 핵 심 질문은 사례별로 달리 구성하였다. 이와 함께 면접 관들이 추가로 질문할 구조화된 탐색 질문을 사례별로 개발하였다. 핵심 질문이 상황에 대한 질문(situational question)인데 비해, 탐색 질문에는 구체적인 자신의 경험에서의 성과를 묻는 질문(accomplishment question)을 위주로 작성하였다[9]. 의사소통과 대인관계 영 역의 경우 추가적인 탐색 질문 과정에서, 앞에 가상의 인물이 있다고 생각하고 이야기해보도록 하였다.

채점표에서 핵심질문에 대한 사례 특이적인 답변을 위주로 하여 이분법적 채점 형태로 9문항을 구성하였 고, 일반적인 태도 영역은 총 3 개의 문항으로 5 점 척도 의 총괄 채점(global rating) 형태로 개발하였다. 채점 기준은 응시자가 명확하게 언급한 경우만 점수를 주는 것으로 정하였다. 단순히 의사소통기술이 뛰어나 잘 할 수 있는, 피상적인 답변보다는 평소 깊은 성찰을 통해 
자신과 사회에 대한 이해가 있을 때 나올 수 있는 답변 위주로 평가할 수 있도록 채점표를 구성하려고 노력하 였다.

개발된 사례와 채점표는 사례개발교수와 면접문항개 발위원들이 모여 여러 차례에 걸쳐 검토하였다. 완성된 사례와 핵심 질문은 Appendix 1 3과 같다.

\section{5. 면접 진행방법}

학생들은 시험장 문에 붙어 있는 사례와 함께 제시된 핵심 질문 3 가지를 2 분에 걸쳐 미리 읽고 8 분 동안 시 험장 안에서 면접관을 만나 면접을 하도록 설정하였다. 학생들이 핵심 질문 3가지에 대해 먼저 답변한 후 면접 관들은 추가로 사전에 구조화된 탐색 질문을 하도록 하 였다.

1 명의 학생을 2 명의 면접관이 독립적으로 채점하도 록 하였다. 면접방에는 응시자에 대한 자료를 놓지 않 았다. 면접관들은 30 40분 간격으로 10 분 이상 휴식하 도록 하였다.

\section{6. 면접 훈련}

본교의 전체 교수를 대상으로 면접평가 워크솝을 4시 간 동안 시행하였다. 워크숍 초반에 외국 입학면접의 형태와 발전사, 그리고 MMI가 출현하게 된 배경 등에 대해 간략하게 설명하였다. 신뢰도와 타당도 높은 평가 를 위한 고려 사항, 그리고 외국의 MMI 결과에 대해서 도 소개하였다. 이후 면접 방법을 면접 분위기 조성, 적 극적 경청, 질문 요령, 채점 요령의 순으로 소개하며 진 행하였다. 교수들은 모의면접을 실제로 해보면서 질문 과 채점 실습을 하였다. 실습을 하면서는 우호적인 분 위기, 효과적인 탐색 질문 하는 법, 교수들의 채점 오류 를 파악하고 평가를 표준화하는 것 등에 집중하였다. 표준화된 질문과 채점기준을 사용할 것, 누가 더 잘하 는가 보다 누가 더 못하는가, 누가 성인군자인가 보다 누가 결격자인가를 중심으로 평가할 것 등을 강조하였 다.

면접 전날 면접에 참여할 교수가 최종 선정되었다. 면접 전날 면접에 참여할 교수들을 대상으로 면접관으
로서 갖추어야 할 태도, 질문 및 채점 방법에 대해 4시 간에 걸쳐 다시 훈련하였다.

\section{7. 실험적 연구}

각 영역에 개발된 사례들 중 각각 1 개씩이 면접 전날 선택되었다. 이 사례들로 면접 전날 실험적 연구(pilot study)를 거쳤다. 2007년 당시 자원한 2학년 학생 8명 을 대상으로 하였다. 면접에 참여할 면접관은 면접을 시행할 공간에서 똑같은 진행방법으로 모의응시자들을 만나 면접하였다. 학생들과 면접관들의 건의사항을 참 고하여 사례와 채점표를 최종 수정하였다.

\section{8. 자료처리 및 분석}

이분법적 채점 항목은 1 점 만점, 총괄채점 항목은 4 점 만점으로 코드화하였다. 영역별 총점과 전체 총점은 백점 만점으로 변환하여 비교하였다. 전체 총점 및 영 역별 총점에서 남녀별, 이공계, 군필, 거주지에 따른 차 이가 있는지 독립표본 $\mathrm{t}$ 검정으로 분석하였다. 연령별 차이가 있는지는 상관분석하였다.

학사과정성적, 공인영어성적, 의학교육입문검사 점 수, 그리고 1 차 입학전형 서류심사에서의 총점과의 상 관관계를 분석하기 위해 상관 분석하였다. 공인영어 성 적은 토플, 토익, 텝스 성적을 인정하였으며 본교의 변환 기준에 의거하여 변환된 점수를 사용하였다. 면접 영역 별 상관관계 또한 상관분석하였다. 상관계수는 Pearson 계수로 구하였다. 상관계수가 0에서 0.2 사이에 있으면 관련 없음, 0.2 에서 0.4 사이에 있으면 약한 관계, 0.4 에 서 0.7 사이이면 보통 관계, 0.7 이상이면 강한 관계로 해석하였다. 통계는 SPSS version 14.0K (SPSS Inc., Chicago, IL, USA)를 이용하여 분석하였다.

신뢰도는 McMaster 대학에서 개발한 urGENOVA 의 Windows 프로그램인 g string 4.1.0 (http://www. mcmaster.ca/perd/download)을 이용하여 일반화가능 도계수로 구하였다. 오차 요인은 면접방(Station, S), 면 접관(Rater, R), 채점항목의 종류(이분법적 채점 또는 총괄채점)(Group, G), 문항(Item, I) 등 4가지로 하였 다. 면접관의 신뢰도는 분산성분에서 면접관 요소를 분 
석하여 구하였다.

면접을 끝낸 응시자들과 면접관들을 대상으로 설문을 실시하였다. 척도 설문의 경우 5점 척도를 사용하였다 (5-매우 그렇다, 4-그렇다, 3-보통이다, 2-그렇지 않 다, 1-매우 그렇지 않다). 그 외 소감 및 건의사항을 주 관식으로 서술하도록 하였다. 모든 응시자와 면접관이 설문에 응답하였다. 설문 결과는 평균과 표준편차를 구 하였다. 주관식 서술은 2 인이 독립적으로 한 구절씩 분 리하여 코드를 매겼다. 학생 서술 내용의 경우 5 회 이상 반복 기술된 내용을 추출하였다. 면접관 서술 내용의 경우 모든 내용을 기술하였다.

\section{결과}

\section{1. 전체 및 영역별 점수}

전체 총점의 평균 점수는 49.21( \pm 9.30$)$ 이었다. 70점 대가 1명(1.19\%), 60점대가 9명(10.71\%), 50점대가 32 명(38.10\%), 40점대가 26명(30.95\%), 30점대가 15명 (17.86\%), 20점대가 1명(1.19\%) 분포하였다(Fig. 2).

직업선택 동기 영역의 총점 평균은 44.01( \pm 11.72$)$ 이 었다. 가치관과 태도 영역의 총점 평균은 51.38 ( \pm 13.87)이었다. 의사소통과 대인관계 영역의 총점 평균 은 $52.23( \pm 16.30)$ 이었다.

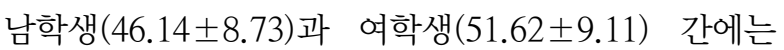

전체 총점 평균의 차이가 있었다 $(\mathrm{p}>0.01)$. 직업선택 동 기 영역과 가치관과 태도 영역에서는 남녀 간 점수의 차이를 보이지 않았다. 의사소통과 대인관계 영역에서 여학생의 점수(57.98 \pm 16.15$)$ 가 남학생 $(44.92 \pm 13.48)$ 에 비해 상당히 높았다(Table 1).

연령과 전체 총점과는 상관관계가 없었다. 이공계 전 공, 군필, 거주지의 차이에 따른 점수의 차이는 없었다.

\section{2. 입학전형에 활용된 다른 성적과의 상관관계}

면접 총점, 각 면접영역별 점수는 학사과정성적, 공인 영어성적, 의학교육입문검사점수와 관계가 없었다 (Table 2). 면접 총점은 대학성적, 영어, 의학교육입문 검사점수를 합친, 1 차 입학전형 서류심사의 총점과 약

Fig. 2. Distribution of the Mean Scores of the Applicants

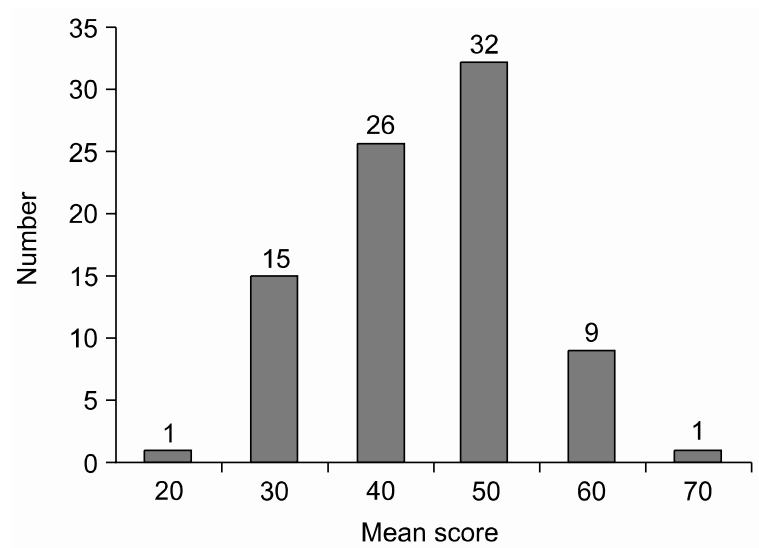

Table 1. Mean Score Difference between Male and Female Applicants in MMI

\begin{tabular}{lcccc}
\hline \multirow{2}{*}{ Applicants } & Domain 1 & Domain 2 & Domain $^{\text {al }}$ & \\
\cline { 2 - 4 } & $\begin{array}{c}\text { Motivation to } \\
\text { become a doctor }\end{array}$ & $\begin{array}{c}\text { Ethical } \\
\text { decision-making }\end{array}$ & $\begin{array}{c}\text { Communication and } \\
\text { interpersonal skills }\end{array}$ & Total $^{\text {a) }}$ \\
\hline Male & $41.76 \pm 11.19$ & $51.76 \pm 12.49$ & $44.92 \pm 13.48$ & $46.14 \pm 8.73$ \\
Female & $45.79 \pm 11.94$ & $51.09 \pm 14.99$ & $57.98 \pm 16.15$ & $51.62 \pm 9.11$ \\
Total & $44.01 \pm 11.72$ & $51.38 \pm 13.87$ & $52.23 \pm 16.30$ & $49.21 \pm 9.30$ \\
\hline
\end{tabular}

MMI: Multiple mini-interview.

${ }^{a}$ group differed significantly $(<0.01)$. 
한 상관관계를 보였다(Pearson 계수 0.220, $\mathrm{p}<0.05$ ).

\section{3. 면접 영역 간의 상관관계}

면접 총점은 모든 면접 영역의 점수와 보통 수준의 상 관관계(0.6 0.7)를 보였다. 직업선택 동기와 가치관과 태도 영역은 서로 약한 상관관계를 보였다(Pearson 계 수 $0.238, \mathrm{p}<0.05)$. 반면 의사소통과 대인관계 영역은 직업선택 동기 영역이나 가치관과 태도 영역과 상관관 계가 없었다(Table 3).

\section{4. $\mathrm{MMI}$ 의 신뢰도}

MMI의 신뢰도(Generalizability coefficient)는 0.791 이었다. 면접관, 면접관과 문항간의 상호작용, 면접관과 응시자, 그리고 문항형태와의 상호작용 등의 분산성분
은 0.0000 이었다. 면접관과 응시자, 그리고 문항 간의 상호작용은 0.5060 으로, 전체 분산성분의 $19.11 \%$ 를 차 지하였다. 전체 분산성분 중 면접관과 응시자와의 상호 작용은 0.4623 으로, $17.46 \%$ 를 차지하였다(Table 4). 분 산성분으로부터 계산해 본 시험관의 일치도는 0.634(= $2.6480-(0.4623+0.5060) / 0.6480)$ 이었다.

\section{5. 학생들의 반응}

\section{1) 5 점 척도 설문 결과}

학생들은 MMI 형태의 시험에 만족한다(4.21 \pm 0.69$)$ 고 답하였다. 학생들은 이러한 평가방식이 약간 낮설었 으며(3.35 \pm 1.03$)$, 다른 면접에 비해 약간 더 긴장하였 다(3.35 \pm 1.03$)$ 고 하였다. 학생들은 이런 형태로 면접한 다는 것을 사전에 알았더라면 본교에 지원하지 않았겠

Table 2. Pearson Coefficient of the MMI Score with the Other Admission Evaluation Tools

\begin{tabular}{|c|c|c|c|c|}
\hline & Domain 1 & Domain 2 & Domain 3 & \multirow{2}{*}{$\begin{array}{l}\text { MMI } \\
\text { total }\end{array}$} \\
\hline & $\begin{array}{l}\text { Motivation to } \\
\text { become a doctor }\end{array}$ & $\begin{array}{c}\text { Ethical } \\
\text { decision-making }\end{array}$ & $\begin{array}{l}\text { Communication and } \\
\text { interpersonal skills }\end{array}$ & \\
\hline MEET & 0.144 & 0.118 & 0.134 & 0.197 \\
\hline GPA & 0.195 & 0.096 & 0.023 & 0.143 \\
\hline English & 0.058 & -0.025 & -0.013 & 0.005 \\
\hline Score of the first selection & 0.193 & 0.119 & 0.136 & $0.220^{\mathrm{al}}$ \\
\hline
\end{tabular}

MMI: Multiple mini-interview, MEET: Medical education eligibility test, GPA: Grade point average.

${ }^{a}$ Significant correlation $(<0.05)$.

Table 3. Pearson Coefficient of the Domains of the MMI Score

\begin{tabular}{|c|c|c|c|c|}
\hline Domain & $\begin{array}{l}\text { Motivation to } \\
\text { become a doctor }\end{array}$ & $\begin{array}{c}\text { Ethical } \\
\text { decision-making }\end{array}$ & $\begin{array}{l}\text { Communication and } \\
\text { interpersonal skills }\end{array}$ & $\begin{array}{l}\text { MMI } \\
\text { total }\end{array}$ \\
\hline Motivation to become a doctor & 1 & & & \\
\hline Ethical decision-making & $0.238^{\mathrm{al}}$ & 1 & & \\
\hline Communication and interpersonal skills & 0.230 & 0.063 & 1 & \\
\hline total & $0.657^{b l}$ & $0.634^{b l}$ & $0.701^{b /}$ & 1 \\
\hline
\end{tabular}

MMI: Multiple mini-interview.

${ }^{a)}$ Significant correlation $(<0.05),{ }^{\text {b) }}$ Significant correlation $(<0.01)$. 
Table 4. Variance Components of the MMI

\begin{tabular}{lcc}
\hline \multicolumn{1}{c}{ Effect } & Degree of freedom & Variance components $(\%)$ \\
\hline P & 82 & $0.0093(0.35)$ \\
S & 2 & $0.0000(0.00)$ \\
R:S & 3 & $0.0000(0.00)$ \\
T:S & 3 & $1.0970(41.42)$ \\
I:T:S & 30 & $0.0569(2.15)$ \\
P:S & 166 & $0.0000(0.00)$ \\
PR:S & 249 & $0.4623(17.46)$ \\
PT:S & 249 & $0.5019(18.95)$ \\
PI:T:S & 2490 & $0.0000(0.00)$ \\
PT:S & 9 & $0.0146(0.59)$ \\
Rl:T:S & 90 & $0.0000(0.00)$ \\
PRT:S & 747 & $0.0000(0.00)$ \\
PRI:T:S & 7470 & $0.5060(19.11)$ \\
Total & 11591 & $2.6480(100.00)$ \\
\hline
\end{tabular}

MMI: Multiple mini-interview, P: Applicant participant, S: Station, R: Rater, T: Type of items, I: Items.

냐는 질문에 아니라고 답하였다(1.42 \pm 0.67$)$. 사례가 특 정 지식을 필요로 하였는지에 대한 질문에도 학생들은 아니라고 대답하였다(2.25 \pm 0.87$)$. 학생들은 사례 내용 이 답변하기에 약간 어려웠지만(3.13 \pm 0.80$)$, 문제는 비 교적 명료하게 제시되었다 $(3.81 \pm 0.84)$ 고 하였다. 학생

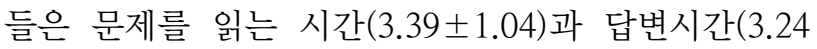
$\pm 0.93)$ 에 대해서는 다른 설문 항목에 비해 비교적 낮 은 만족도를 주었다. 학생들은 진행요원이 아주 친절하

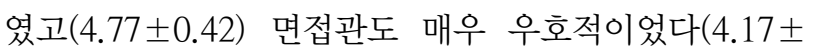
0.80)고 답하였다.

\section{2) 서술식 답변}

학생들은 MMI 방식이 신선하고 재미있어 좋은 면접 이었다 $(n=6)$ 고 기술하였다. 학생들은 이번 MMI를 통 해 학교에 대한 기대를 갖게 되었다 $(\mathrm{n}=6)$ 고 하였다. 학 생들은 면접 도중 긴장되었지만 $(\mathrm{n}=13)$, 공정하고 적절 한 평가였다 $(n=15)$ 고 하였다. 학생들은 열정을 다해 준 비해준 본교에 감사하였으며 $(\mathrm{n}=10)$ 편하게 면접을 볼 수 있었다 $(\mathrm{n}=8)$ 고 답하였다.

학생들은 사례 내용이 현실에서 충분히 경험해밨음 직한 상황이었으며, 평소 간과하기 쉬운 부분을 포함하
고 있어 사고의 전환을 하는 계기가 되었으며 흥미로웠 다 $(n=6)$ 고 답하였다. 학생들은 사례가 이해하기 쉬웠으 나 $(\mathrm{n}=8)$, 답변하기는 어려웠다 $(\mathrm{n}=10)$ 고 답하였다. 질문 이나 사례에 다소 애매모호한 부분이 있어 좀 더 구체 적으로 기술되면 좋겠다 $(\mathrm{n}=7)$ 고 하였다. 학생들은 미리 준비해온 의료 관련 지식을 이야기하거나, 바람직한 의 사상에 대한 자신의 견해를 피력하거나, 개인의 장점 등의 자기 소개를 할 기회가 없었다며, 이러한 질문도 함께 이루어지기를 희망하였다 $(\mathrm{n}=5)$.

학생들은 MMI가 체계적이고 매끄럽게 진행되었다 $(n=12)$ 고 만족해하였다. 학생들은 문제를 읽는 시간으 로 2 분이 짧아 깊이 생각하기에 부족하였다 $(\mathrm{n}=22)$ 고 하 였다. 학생들은 진행요원이 친절하게 응대해주어 매우 만족스러웠다 $(\mathrm{n}=19)$ 고 하였다. 면접관에 대해서도 편 하게 대해주고 답변을 말하기 쉽도록 유도해주셔서 좋 았다 $(n=10)$ 고 하였다. 그럼에도 일부 학생들은 면접관 의 긴장되고 엄숙한 분위기에 더 긴장되기도 하였다 $(\mathrm{n}=5)$ 고 하였다.

\section{6. 면접관들의 반응}

\section{1) $\mathrm{MMI}$ 에 대한 면접관들의 5점 척도 설문 결과}

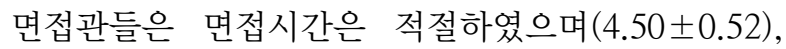
사례는 응시자 수준에 적절하였다(4.14 \pm 0.66$)$ 고 답하 였다. 면접관들은 스스로가 비교적 공정하게 평가하였 다(3.85 \pm 0.52$)$ 고 대답하였다. 사례 제시문(3.50 \pm 0.86$)$ 과 채점표(3.64 \pm 0.93$)$ 에 대한 만족도는 다른 항목에 비해 낮았다.

\section{2) $\mathrm{MMI}$ 에 대한 면접관들의 서술식 답변}

한 학생을 대상으로 3 개 방과 6 명의 면접관으로 이루 어진 $\mathrm{MMI}$ 로는 다양한 관점을 평가하기에는 한계가 있 으며, 문항 개발과 면접관 수 증가가 필요하다는 지적 $(n=4)$ 이 있었다. 면접관들은 사례가 응시자가 이해하기 쉽도록 좀 더 구체적이고 명확하게 제시되어야 한다 $(n=6)$ 고 하였다. 한 면접관은 사고력과 윤리의식 등을 더 잘 평가할 수 있는 사례면 좋겠다고 하였다. 다른 한 면접관은 학생들, 특히 남학생의 경우 연기하듯 가상의 인물을 앞에 놓고 이야기하는 것을 부담스러워하므로 
앞에 실제 대상이 있으면 좋겠다고 하였다.

면접관들은 질문 중 애매모호하거나 추상적인 부분 이 있어 예상하지 못하였던 응시자의 답변이 있을 때 대처하기 어려웠기에, 보다 구체적이고 명확한 질문이 개발되어야 한다 $(n=9)$ 고 하였다. 면접관들은 이분법적 항목의 경우 평가하기에는 좋으나, 면접하는 동안 발생 하는 모든 상황을 포함하기에는 부족하다 $(\mathrm{n}=7)$ 고 지적 하였다. 본인의 생각이 아니라, 마치 연기를 하는 듯 모 범 답안을 이야기하는 학생들에 대한 대책이 마련되어 야 한다는 지적도 있었다 $(\mathrm{n}=2)$.

면접관들은 면접의 진행방법이나 시간에 대해서는 전반적으로 매끄러웠다 $(n=4)$ 고 하였다. 일부 학생들은 문제를 이해하기에 문제 읽는 2분이 부족한 경우가 있 었다고 한 면접관이 기술하였다.

\section{고찰}

면접은 면접관과 응시자가 서로 대화를 통해서 얻고 자 하는 자료나 정보를 수집하여 평가하는 방법이다[4]. 따라서 면접에 의한 평가는 면접관의 선입견이나, 응시 자의 특성과 의사소통능력 등에 의해 좌우될 수 있다 $[5,10]$. 주관적 판단에 의하지 않은, 신뢰 있는 평가가 되기 위해서는 별도의 노력이 필요하다. 모든 응시자에 게 표준화된, 똑같은 질문을 하고, 질문에 대한 견본 답 변을 제공하며, 면접관을 훈련하고, 다수의 면접관을 사 용하는 구조화 면접이 신뢰도를 향상시킨다고 여러 연 구에서 보고하고 있다[8,10,11]. 모든 응시자에게 표준 화된, 똑같은 질문을 함으로써 응시자는 공정한 면접 기회를 가지게 된다. 견본 답변을 제공하고 면접관을 훈련함으로써 일관성 있고 객관적인 평가가 가능하게 된다. 다수의 면접관을 사용함으로써 면접관의 편견이 희석된다.

$\mathrm{MMI}$ 는 모든 응시자에게 표준화된, 똑같은 사례를 주 고 질문에 대한 견본 답변을 제공하며, 다수의 면접관을 사용하는 구조화 면접의 일종이다. MMI는 기존의 구조 화 면접에서 더 나아가 짧은 시간 다수의 사례를 사용함
으로써 신뢰도를 더 높인 것이다. 캐나다 McMaster 의 과대학에서 사용한 $\mathrm{MMI}$ 의 방법은 다음과 같다[5]. 이 들은 비판적 사고, 윤리적 의사결정, 의사소통기술, 보 건의료시스템에 대한 이해, 그리고 직업선택 동기 등 총 5 가지 영역에서 면접을 시행하였다. 이들은 한 영역 당 2 개의 사례를 개발하여 모두 10 개의 사례로 학생을 면접하였다. 의사소통기술을 평가하는 면접방에서는 표 준화환자를 활용하였다. 각 방의 면접 시간은 8 분이었 고 2 분의 사이 시간을 두었다. 면접관은 각 방에 1 인씩 배치하였다. 면접관은 교수, 학생, 지역사회 인사로 구 성하였다. 면접관은 면접을 끝낸 후 학생에 대한 총괄 평가를 7점 척도로 하였다. Calgary 의과대학의 경우 9 개의 8 분짜리 면접방에서 $\mathrm{MMI}$ 를 시행하였으며, 5 개의 평가문항에서 10점 척도로 평가하였다[12]. 일반화가능 도 이론에 의한 연구결과, 1 개의 면접방에 12 명의 면접 관이 한꺼번에 들어가는 경우, 신뢰도는 0.55 에 그치지 만, 12 개의 면접방에 각각 1 인의 면접관이 들어가는 경 우 신뢰도는 0.85 였다. 사례를 많이 사용하고 각 사례 당 채점자 수를 제한하는 것이 사례를 적게 하고 채점 자를 많이 동원하는 것보다 신뢰도가 좋다는 것이다. Eva et al.[5]은 신뢰도를 높이기 위해 사례가 다른 면 접방의 수를 늘릴 것을 제안하였다.

$\mathrm{MMI}$ 의 장점은 응시자의 능력을 다각도에서 평가할 수 있으며, 응시자가 한 방에서 면접관에게 실수를 하 였더라도 다른 방에서 만회할 기회가 있다는 것 등이다 [5]. 그 외에도 응시자가 면접 받는 시간이 증가한다는 것, 그에 비해 면접관이 면접하는 시간의 증가는 없다 는 것, 면접관이 다른 면접관의 영향을 받지 않고 독립 적이고 주도적인 평가가 가능하다는 것, 이를 통해 면 접관 또한 시간의 부담을 줄이면서도, 신뢰 있고 공정 한 평가가 가능해진다는 것 등이 $\mathrm{MMI}$ 의 장점이다.

본 연구결과 응시자들은 $\mathrm{MMI}$ 가 공정한 평가였다고 답하였다. 신뢰도는 0.791 로 상당히 높았다. 이러한 결 과는 공정성과 신뢰도를 높이려는 본 연구의 노력이 결 실을 거둔 것으로 생각된다. 0.791 정도의 신뢰도가 입 학면접에서 당락을 결정하기에 충분한가에 대해서는 신중하게 검토되어야 한다. 중요한 당락이 결정되는 평 
가의 경우 0.90 이상의 신뢰도가 필요하다[13]. 입학선 발면접에서의 당락이 응시자에게 있어 매우 중요하다 는 것을 볼 때, 신뢰도를 더 높여야 할 것으로 생각된다. 나이, 인종 등의 응시자의 특성이 면접 당락에 영향 을 미칠 수 있다고 보고되고 있다[14]. 본 연구결과, $\mathrm{MMI}$ 의 전체 점수는 나이, 전공, 거주지 등에 따른 차이 를 보이지 않았다. 사례 수준에 대해서도 응시자나 면 접관 모두 적절하였다는 반응을 보였다. 이는 나이가 많고 적음, 이공계나 인문계, 서울 등 정보를 쉽게 얻을 수 있는 거주지이거나 그렇지 않은 지방이거나 등 어떤 특성을 가진 응시자에게라도 MMI가 동등하게 기회를 제공하였음을 의미한다.

$\mathrm{MMI}$ 총점은 여자 응시자에서 약간 더 높았다. 의사 소통 영역의 경우, 여학생의 점수가 남학생에 비해 매 우 높았다. 여학생의 경우, 공감이나 의사소통 능력이 남학생에 비해 뛰어나다[2]. 또한 기존 연구에서는 면접 에서 성별에 따라 불공정한 평가를 받는다고 보고하고 있다[9,14]. 본 연구에서는 사례와 질문, 그리고 채점표 를 개발하는 과정에서 어느 한쪽에 불이익이 없도록 노 력하였다. 의사소통 영역의 점수 차이에도 불구하고 전 체 총점의 차이가 크지 않음은, MMI가 남녀의 차이나 의사소통기술의 차이에 의해 불공정하게 평가될 수 있 는 부분을 상당부분 보완하였음을 의미한다.

$\mathrm{MMI}$ 점수는 학사과정성적, 공인영어성적, 의학교육 입문검사점수와 상관관계가 없었다. 이 결과는 $\mathrm{MMI}$ 가 성적에 의한 후광효과를 배제하는 데 일조하였음을 알 려준다. 응시자의 성적을 면접관에게 공개한 경우 면접 관들이 인성 영역 평가에 영향을 받았다고 보고되고 있 다[14,15]. 공정한 평가를 위해 면접관에게는 응시자에 대한 어떠한 정보도 주어서는 안 된다[12]. 본 면접에서 응시자의 기본 인적사항 자료를 면접방에 배치하지 않 고 이름 이외의 어떤 정보도 면접관에게 알리지 않은 이유는 바로, 면접관의 편견에 의한 후광효과를 예방하 고 공정한 평가를 하기 위한 목적이었다.

면접의 신뢰도가 높기 위해서는, 채점기준에 표준화 된 일관성 있는 면접관의 채점이 필요하다. 기존 연구 에서 구조화 면접의 경우 면접관의 일치도가 높다고 보
고되고 있다[1,10,11]. 본 연구결과, 면접관의 일치도는 0.634 였다. 면접관의 일치도를 낮춘 요인은 주로 응시 자나 문항과의 상호작용에서 발생하였다. 또한 사례 제 시문과 채점표에 대한 만족도가 비교적 낮았다. 따라서 면접관의 신뢰도를 높이기 위해서는 응시자나 문항과 의 상호작용에서 발생할 수 있는 오류를 제거하는 것이 필요하다. 응시자와의 상호작용에서 발생하는 문제는 채점자 훈련을 통해 채점 오류를 예방하고, 다수의 사 례를 제시하여 다양한 각도에서 평가함으로써 극복할 수 있을 것으로 생각된다. 문항에서 발생한 문제는 문 항을 명료하고 구체적으로 제시함으로써 해결할 수 있 을 것이다.

면접에서의 평가자들이 자신의 평가에 확신을 갖기 가 쉽지 않다. 연구에 따르면 평가에 대한 주관적 확신 은 전체 면접시간에 비례하였다[10]. 평가자는 30분 이 하의 면접에서는 평가 결과에 확신을 갖지 못하였다. Pendleton \& Wakeford[10]는 면접에 최소한 1시간은 필요하다고 하였으며 1시간을 여러 명 이상의 평가자가 나누어 써도 된다고 하였다. 본 연구에서는 총 24 분의 면접시간을 사용하였다. 면접관들이 자신의 판단에 확 신을 갖기 위해서는 신뢰도를 높이는 다른 노력들과 함 께 좀 더 긴 면접시간 또한 필요할 것으로 생각된다. 이 번 MMI에서는 한 면접방에 2명의 면접관이 함께 들어 갔다. 만약 한 면접방에 1 명의 면접관이 들어간다면, 응 시자에게는 면접 시간과 접하게 되는 사례 수가 2배로 늘어나면서 면접시간은 2 배가 된다. $\mathrm{MMI}$ 의 경험이 어 느 정도 축적된 후에는 한 면접방에 1 명의 면접관을 투 입하고 대신 사례 수를 늘리는 것이 더 바람직할 것으 로 생각된다.

외국 사례에서는 교수나 의사, 보건의료종사자, 지역 사회인사, 학생 등 다양한 배경의 면접관을 활용하여 면접을 시행하고 있다[7,11]. Eva et al.[16]은 같은 응 시자에 대한 교수와 지역사회인사의 평가를 분석하였 을 때 그 일치도가 낮았다고 보고하며, 다양한 배경을 가진 면접관을 활용함으로써 다양한 배경의 응시자를 선발할 수 있다고 하였다. 본 MMI에서는 의학전문대학 원 교수만을 면접관으로 활용하였다. 다양한 전공과목 
과 남녀 교수를 활용하였지만, 정신과 전공은 없었다. 정신과 의사나 심리학자와 같은, 특별히 전문화된 면접 관은 비정상적인 성격 특성을 가진 응시자를 골라내는 데 필요할 수 있다[9]. 향후 면접관을 다양화하는 노력 은 시도되어야 할 것이다.

그동안 면접의 중요성에 비해 면접의 필요성에 대한 믿음은 뚜렷하지 않았다[17]. 기존 연구에서는 면접 점 수가 다른 입학전형 영역의 점수와 낮거나 보통의 상관 관계를 보였다[5]. 본 연구결과에서 $\mathrm{MMI}$ 점수와 학사 과정성적, 공인영어성적, 의학교육입문검사점수와 상관 관계가 없었는데, 이는 MMI가 면접 이외의 영역에서는 평가하지 못하는 영역을 평가하고 있음을 의미한다. 따 라서 입학전형에서의 다른 자료를 통해 인성 관련 정보 를 얻는다 하더라도 면접은 인성 영역에서의 평가로서 그 가치가 있으며 또한 필요하다고 생각된다.

면접에서는 의학전문대학원에서 가르쳐질 수 없는 영역을 평가해야한다는 인식이 많다[15]. Bullimore [18]는 정직성 등의 인적 특성은 18세까지 형성되므로, 의학전문대학원 선발면접에서 중요하게 평가해야한다 고 하였다. 그러나 과연 어떤 영역이 어린 시절 형성된 후 고착화되어 변하지 않고 어떤 영역은 비교적 유연한 지, 어떤 영역을 의학전문대학원 면접에서 평가하는 것 이 좋은지에 대해 뚜렷이 제시된 연구는 아직 없다[17]. 기존 연구에서는 의사소통기술, 공감, 정직성, 윤리성, 성실성, 직업선택 동기, 유연성, 의사결정능력, 문제해 결능력, 팀워크, 비판적 사고력, 논리적 사고력, 인내력, 자기 확신, 리더십 등이 시도되고 있다[2,8,11,12,18]. Lowe et al.[19]은 윤리적 지식이나 도덕적 추론, 윤리 적 주제에 대한 신념 등은 의학전문대학원 교육과정을 통해 얼마든지 배울 수 있는 것들이므로, 굳이 평가할 필요는 없다고 하였다. 반면, 윤리적 이슈에 대한 태도 나 윤리적 민감성은 타고난 것이며, 잘 변하지 않기에 타당성 있는 검사를 통해 평가되는 것이 바람직하다고 하였다. 본 연구에서는 윤리적 지식이나 주입된 신념을 평가하기보다는, 윤리적 문제점을 발견해내는 민감성이 나 태도를 평가하기 위해 사례 개발 과정에서 주의를 기울였다. 향후 의학전문대학원 면접에서 면접이 필요
한 영역에 대해서는 심도 있는 연구가 이루어져야 할 것이다.

연구결과 응시자와 면접관은 사례당 면접시간에 대 해 서로 상반된 견해를 보였다. 응시자의 경우, 면접시 간에 대한 만족도가 떨어졌지만, 면접관들은 면접시간 이 적절하다고 하였다. 반면 응시자와 면접관 모두 문 제를 읽는 시간이 부족한 경우가 있었다고 호소하였다. 여러 연구에서 문제를 읽는 시간을 2 분으로 하고 있다 [5,12]. 문제를 읽는 시간이 길어질 경우, 전체적인 면 접 진행시간이 늘어나게 된다. 문제를 읽는 시간을 제 한할 경우, 제한된 시간에 문제의 의미를 파악하고 논 리적으로 사고하는 능력이나, 응시자 본연의 평소 생각 이나 신념 등을 끌어내기가 더 용이할 것으로 생각된다. 문제 읽는 시간을 어떻게 얼마나 배치할지에 대해서는 차후 연구가 더 필요하겠다.

본 MMI에서는 의사소통 영역을 평가하기 위해 앞에 가상의 인물이 있다고 가정하고 이야기해보도록 하였 다. 외국 사례에서는 의사소통 영역을 평가하기 위해 표준화환자를 사용하기도 한다[5]. 의사소통과 대인관 계 기술은 수행능력이며, 따라서 면접에서 말로 평가하 기에는 부족함이 있다. 표준화환자를 활용하면, 응시자 가 표준화환자를 대하는 태도를 관찰함으로써, 의사소 통과 대인관계에 대한 능력을 객관적으로 평가할 수 있 게 된다. 응시자 또한 가상의 인물을 앞에 두고 대화를 하는 것에 비해 실재감을 느껴 자신의 의사소통 능력을 더 잘 발휘할 수 있게 된다. 면접경험이 쌓임에 따라 향 후에는 표준화환자 또한 면접에 활용하는 것이 바람직 할 것이다. 또한 연구 결과, 의사소통 영역은 직업선택 동기 영역이나 가치관과 태도 영역과 상관관계가 없었 다. 따라서 최소한 의사소통 영역은 정직성이나 직업선 택 동기와는 분리된 영역으로 평가되어야 할 것으로 생 각된다.

MMI에 대한 응시자들의 반응은 매우 긍정적이었다. 특히 이들은 면접 진행이나 면접 과정에서의 진행요원 과 면접관의, 친절하고 응시자를 존중하는 태도를 보고 긴장감이 누그러졌으며, 학교에 대한 호감도 가지게 되 었다고 하였다. 이는 우호적인 분위기를 강조하였던 채 
점 훈련 워크숍이 성공한 것으로 생각된다. 또한 여기 서 면접이 학교의 이미지를 좋게 하는 효과도 있다는 것을 알 수 있다. 만약 응시자가 존중받고 학교에서 응 시자에게 시간과 주의를 기울인다면 그 학교는 더 좋은 응시자를 끌어들일 것이다[9].

본교 입학전형회의에서는 기밀 유지를 가장 중요시 하였다. 기밀 유지는 모든 응시자에게 공정한 기회를 제공하는 측면에서 중요하였다. 만약 면접과 관련된 기 밀이 일부 응시자에게만 누설된다면, 이는 면접의 공정 성은 물론, 신뢰성과 타당성에 심각한 위해를 끼치기 때문이다. 이에 따라 타당도 높고 신뢰 있는 채점을 위 한 사례 개발, 다양한 배경의 면접관 동원 등은 제한을 받았다. 타당성과 신뢰도가 낮은 사례, 획일화된 배경의 면접관 등은 응시자에게 공정한 기회를 제공하는 것을 제한한다. Reiter et al.[20]은 MMI를 시행하기 2주 전 에 $\mathrm{MMI}$ 에 대한 정보를 접한 응시자와 그렇지 않은 응 시자 간에 평가 결과의 차이가 없었다며, 사례가 미리 공개되어도 평가에는 영향을 주지 않았다고 결론지었 다. 이러한 연구 결과가 우리나라에서도 일반화될 수 있을지에 대해서는 의문의 여지가 있다. 그러나 진정으 로 응시자에게 공정한 기회가 될 수 있도록 하기 위해 서는 기밀 유지와 타당한 사례개발이나 공정한 면접관 동원 등이 균형을 잘 맞추어야 할 것이다. 또한 우리나 라에게 $\mathrm{MMI}$ 를 비롯한 구조화 면접이 잘 이루어지기 위해서는 무엇보다 기밀 유지의 필요성을 불러일으킨, 면접에 대한 불신을 없애도록 노력하는 작업이 같이 수 행되어야 할 것으로 생각된다. 1 년 내내 면접을 시행하 는 외국의 경우 기존 면접에 비해 MMI가 시간과 인력 동원, 노력이 적게 드는 방법이다. 하지만 단기간에 면 접을 끝내는 우리나라의 경우, $\mathrm{MMI}$ 는 기존 면접에 비 해 그 부담이 크다. 우리나라 학교 보직자나 교수, 그리 고 응시자들이 입학 면접에 대해 어떻게 생각하고 있는 지, 무엇을 기대하는지, 무엇을 두려워하고 있는지에 대 한 조사를 통해 면접에 대한 불신을 해소할 방안도 나 올 것이다. 또한 우리나라에서 MMI가 받아들여지기 위 해서는 MMI의 부담을 줄일 수 있는 방법이 함께 연구 되어야 할 것이다.
본 연구의 제한점은 첫째, 우리나라에서 시행해왔던 기존의 면접과 비교하여 MMI가 더 신뢰도가 높은지, 어떤 장단점이 있는지 분석하지는 못하였다는 것이다. 우리나라에서 그동안 시행되었던 기존의 면접 방법의 신뢰도와 장단점에 대한 연구는 찾을 수 없었다. 둘째, 동일한 환경에서 구조화 면접과 비교하였을 때, MMI가 더 신뢰도가 높은지, 현실적인지에 대한 연구가 연구 설계 과정에서 포함되지 못하였다. 입학 전형의 특성 상 면접의 형태를 응시자별로 달리 하기는 어려웠기 때 문이다. 셋째, 기밀 유지의 필요성으로 인해, 사례개발 이나 다양한 면접관의 활용은 제한되었다. 넷째, 실제 면접현장에서 남녀 차별적인 요소가 있었는지 평가하 지는 못하였다. 면접장면은 녹화나 녹음을 하지 않았기 에 차후에 확인하기도 어려웠다. 다섯째, 일개 의학전문 대학원의 결과이므로, 우리나라 전체에 일반화하는 데 에는 제한이 있을 수 있다.

결론적으로 $\mathrm{MMI}$ 는 연령, 전공, 거주지 등과 관계없 이 공정하게 시행될 수 있었고 그 신뢰도도 높았다. $\mathrm{MMI}$ 에 대한 응시자들과 면접관들의 반응은 매우 긍정 적이었다. MMI는 1 차 전형 성적과는 상관관계가 없어, 면접이 필요하였음을 알 수 있었다. 면접관의 일치도를 낮춘 요인은 주로 응시자나 문항과의 상호작용에서 발 생하였다. 준비 과정에서는 기밀 유지에 의해 사례 개 발이나 면접관 선발에 제한을 받았다. $\mathrm{MMI}$ 의 신뢰도와 타당도를 더 높이기 위해서는 보다 철저한 사례개발과 다수의 사례, 다양한 면접관이 필요하겠으며, 면접에 대 한 불신을 해소하려는 노력이 함께 되어야 한다.

\section{ACKNOWLEDGEMENTS}

The authors would like to express their gratitude to the interviewers, applicants and pseudoapplicants who participated the MMI. We would also like to thank our staffs of the school of medicine, each of whom organized and kept the process of the MMI. 


\section{REFERENCES}

1. Morrison J. How to choose tomorrow's doctors. Med Educ 2005; 39: 240-242.

2. Lumsden MA, Bore M, Millar K, Jack R, Powis D. Assessment of personal qualities in relation to admission to medical school. Med Educ 2005; 39: 258-265.

3. Hughes P. Can we improve on how we select medical students? J R Soc Med 2002; 95: 18-22.

4. Lee K. Simcheungmyeonjeop: Je12cha Uihakgyoyukhapdonghaksuldaehoe gyeolgwabogoseo. Seoul, Korea: Araminswae; 2002. p 131-145.

5. Eva KW, Rosenfeld J, Reiter HI, Norman GR. An admissions OSCE: the multiple mini-interview. Med Educ 2004; 38: 314-326.

6. Park H, Han J, Park M, Oh J. Comparison of results from objective structured clinical examinations for medical students performed before and after clinical clerkship. Korean J Med Educ 2004; 16: 63-71.

7. Brownell K, Lockyer J, Collin T, Lemay JF. Introduction of the multiple mini interview into the admissions process at the University of Calgary: acceptability and feasibility. Med Teach 2007; 29: 394-396.

8. Harris S, Owen C. Discerning quality: using the multiple mini-interview in student selection for the Australian National University Medical School. Med Educ 2007; 41: 234-241.

9. Edwards JC, Johnson EK, Molidor JB. The interview in the admission process. Acad Med 1990; 65: 167177.

10. Pendleton D, Wakeford R. Interviews in the selection of partners, trainees, and medical students. J R Coll Gen Pract 1988; 38: 147-148.
11. Searle J, McHarg J. Selection for medical school: just pick the right students and the rest is easy! Med Educ 2003; 37: 458-463.

12. Lemay JF, Lockyer JM, Collin VT, Brownell AK. Assessment of non-cognitive traits through the admissions multiple mini-interview. Med Educ 2007; 41: 573-579.

13. Downing SM. Reliability: on the reproducibility of assessment data. Med Educ 2004; 38: 1006-1012.

14. McManus IC. Factors affecting likelihood of applicants being offered a place in medical schools in the United Kingdom in 1996 and 1997: retrospective study. BMJ 1998; 317: 1111-1116; discussion 11161117.

15. Shaw DL, Martz DM, Lancaster CJ, Sade RM. Influence of medical school applicants' demographic and cognitive characteristics on interviewers' ratings of noncognitive traits. Acad Med 1995; 70: 532536.

16. Eva KW, Reiter HI, Rosenfeld J, Norman GR. The relationship between interviewers' characteristics and ratings assigned during a multiple mini-interview. Acad Med 2004; 79: 602-609.

17. Albanese MA, Snow MH, Skochelak SE, Huggett $\mathrm{KN}$, Farrell PM. Assessing personal qualities in medical school admissions. Acad Med 2003; 78: 313-321.

18. Bullimore DW. Selection interviewing for medical school admission. Med Educ 1992; 26: 347-349.

19. Lowe M, Kerridge I, Bore M, Munro D, Powis D. Is it possible to assess the "ethics" of medical school applicants? J Med Ethics 2001; 27: 404-408.

20. Reiter HI, Salvatori P, Rosenfeld J, Trinh K, Eva KW. The effect of defined violations of test security on admissions outcomes using multiple mini-interviews. Med Educ 2006; 40: 36-42. 
You are the 2nd-year medical student. You served as a student doctor for medical service volunteers in the rural area of Gangwon-do. You met the old man who lived alone. He suffered from Diabetes Mellitus. You recommended him to go to the hospital for further evaluation and management.

But, he refused your offer because he had no money, no hospital near hear, and no person who send him to hospital. He couldn't get basic healthcare because he had a son in the family register. However, his son's whereabouts is unknown and nobody cares him.

Answer the following questions about this case and provide your reasoning.

1. What are the problems in this case?

2. What would you do?

3. What are your values and principles to solve the problem?

Appendix 2. Case of Honesty and Ethical Behavior

You are the student taking the "understanding the contemporary art" class. The task had been set to your team and you were finding the proper references with your teammate in the library.

One of your teammate found the excellent book including the suitable figure, but it was impossible to copy or lend the book due to the copyright issue. You and your teammate tried to find other appropriate books. You witnessed the sight that your teammate tore off the figure sheet from the book and put it into his bag. He said "mission finished, let's get out of here silently" and then left the library.

Answer the following questions about this case and provide your reasoning.

1. What are the problems in this case?

2. What would you do?

3. What are your values and principles to solve the problem?

Appendix 3. Case of Empathy and Communication Skills

Cheolsoo is a 15 year-old boy and broke his leg during the soccer. On X-ray, bone cancer was suspected. To confirm the bone cancer, biopsy should be performed. There is the possibility of amputation of his leg in case of bone cancer. He had lost his father with liver cancer two years ago.

His mother was told about biopsy. His mother asked you, doctor, to deliver the news instead of her.

Answer the following questions about this case and provide your reasoning.

1. What are the feeling of his mother?

2. What are the feeling of Cheolsoo?

3. What would you do? 